\title{
Selenium Status, Its Interaction with Selected Essential and Toxic Elements, and a Possible Sex-Dependent Response In Utero, in a South African Birth Cohort
}

\author{
Halina B. Röllin ${ }^{1,2, *(D)}$, Kalavati Channa ${ }^{3}$, Bukola Olutola ${ }^{1,4}$ and Jon Øyvind Odland ${ }^{1,5,6}$ (D) \\ 1 School of Health Systems and Public Health, Faculty of Health Sciences, University of Pretoria, \\ Pretoria 0002, South Africa; Bukola.Olutola@gmail.com (B.O.); Jon.o.odland@ntnu.no (J.Ø.O.) \\ 2 Environment and Health Research Unit, South African Medical Research Council, \\ Johannesburg 2094, South Africa \\ 3 Department of Analytical Chemistry, Lancet Laboratories, Johannesburg 2090, South Africa; \\ kalavati.channa@lancet.co.za \\ 4 School of Engineering, IT, Science and Health, Independent Institute of Education-Monash, \\ Roodepoort 1724, South Africa \\ 5 Department of Community Medicine and Nursing, Faculty of Health Sciences, University of Science and \\ Technology, N-7491 Trondheim, Norway \\ 6 Department of General Hygiene, I.M. Sechenov First Moscow State Medical University (Sechenov University) \\ 119435 Moscow, Russia \\ * Correspondence: halina.rollin@up.ac.za; Tel.: +27-12-356-3261
}

check for

updates

Citation: Röllin, H.B.; Channa, K.; Olutola, B.; Odland, J.Ø. Selenium Status, Its Interaction with Selected Essential and Toxic Elements, and a Possible Sex-Dependent Response In Utero, in a South African Birth Cohort. Int. J. Environ. Res. Public Health 2021, 18, 8344. https:// doi.org/10.3390/ijerph18168344

Academic Editor: Alberto Mantovani

Received: 10 May 2021

Accepted: 3 August 2021

Published: 6 August 2021

Publisher's Note: MDPI stays neutral with regard to jurisdictional claims in published maps and institutional affiliations.

Copyright: (c) 2021 by the authors. Licensee MDPI, Basel, Switzerland This article is an open access article distributed under the terms and conditions of the Creative Commons Attribution (CC BY) license (https:/ creativecommons.org/licenses/by/ $4.0 /)$

\begin{abstract}
Selenium (Se) is an essential trace element and its deficiency in utero may affect fetus development and birth outcomes. The current study aimed to assess serum Se status at delivery and examine the possible association between Se levels and birth outcomes. The interaction of Se with selected essential and toxic elements as well as possible sex-dependent responses in utero were also evaluated. The negative association between Se levels and head circumference of neonates was evident in the total cohort $(\beta=-0.164 ; p<0.001)$ as well as in the pre-term and full-term cohorts. Significant positive correlations were found between maternal serum Se concentrations and zinc $(\mathrm{Zn})$ and copper $(\mathrm{Cu})$ in the total and regional cohorts. In the total cohort, the toxic elements lead $(\mathrm{Pb})$ and arsenic (As) showed a negative correlation with Se levels, while mercury ( $\mathrm{Hg})$, aluminum ( $\mathrm{Al})$ and cadmium (Cd) showed a positive correlation. The study found a sex-dependent response in utero for $\mathrm{Zn}, \mathrm{Cu}, \mathrm{Pb}, \mathrm{Hg}$, and $\mathrm{Al}$. The findings of the current study may inform reproductive health policy on Se status in South Africa and highlight the need for sensitive methods to measure Se intake during pregnancy and its complex interactions with other micronutrients and environmental pollutants.
\end{abstract}

Keywords: selenium in utero; essential elements; toxic elements; birth outcomes; sex-dependent response

\section{Introduction}

Selenium (Se) is an essential trace element and its status in humans and other mammals depends primarily on dietary intake, with the main sources being meat, cereals, and seafood [1]. Globally, the intake of Se in the diet is affected by the geosphere that differs by geographical positions of the population [2]. Dietary Se deficiency is particularly evident in many regions where agricultural soils producing staple crops are naturally Se-deficient, necessitating bio-fortification of soils in some countries [3]. The U.S. Institute of Medicine (IOM) has the recommended daily allowance (RDA) for Se set at $55 \mu \mathrm{g}$ for adults, with the RDA for pregnant women set at $60 \mu \mathrm{g}$ [4]. The European Food Safety Authority (EFSA) set a reference intake of $70 \mu \mathrm{g} /$ day for adult men and women based on the relationship between intake of Se and plasma selenoprotein P (SEPP1) concentration [5].

The levels of Se are highly regulated in biological systems and incorporated into selenoproteins. Se plays an integral role in immune function and antioxidant defense, with 25 genes expressing selenoproteins in the human genome [6-9]. Se is also involved in 
the metabolism of thyroid hormones and reproduction $[10,11]$. When present in adequate concentrations in human systems, and due to its enzymatic functions, Se has been shown to exert many beneficial health effects such as prevention of cardio- and neuro-defects, prevention of cancer, and increasing immune-competence and reproductive capacity [12-16].

Number of studies have shown that Se can easily be transferred from the mother to the fetus ([17-19]). The free trans-placental passage of Se indicates the strong dependence of the developing fetus on the Se levels of their mothers [20]. It has been reported that Se passes the placental barrier by a passive, diffusion-mediated mechanism across the placental membrane [21].

In humans, Se deficiency may affect the heart, weaken the immune system, and cause hypothyroidism [22-24]. For example, Keshan disease (cardiomyopathy disease of the heart muscle) and Kashan-Beck disease (a disorder of the cartilage and bone) are linked to Se deficiency [25]. On other hand, it has been shown that adequate levels of Se may reduce cardiomyopathy in women and children with Keshan disease [26,27]. Furthermore, Se deficiency is associated with sepsis, arteriosclerosis, cancer, cognitive decline, and higher mortality rate in older persons $[28,29]$.

It is of concern that low Se status during pregnancy may result in adverse pregnancy outcomes such as miscarriages and premature birth, neural tube defects, low birth weight, and gestational diabetes [30-32]. Furthermore, many of these adverse pregnancy outcomes have been reported in women infected with the human immunodeficiency virus (HIV) and their offspring [33]. It is reported that in mothers with hypothyroidism, complications such as miscarriage and pre-eclampsia are common, as are impaired motor function in neonates and speech disorders in infants [34]. An excess of Se in humans, resulting mainly from environmental and accidental exposures or uncontrolled intake of Se supplements, may cause selenosis, a condition that presents with hypotension, tachycardia, gastrointestinal symptoms, neurological dysfunction and fetor oris (halitosis) [35].

It is understood that since Se is an essential trace metalloid, it plays a detoxification role in metal toxicity by mitigation of cadmium (Cd) and arsenic (As) induced tissue injuries [36-38]. It has been shown in animal models that Se also reduces the toxicity of mercury $(\mathrm{Hg})$ by making it biologically inert through its binding to selenite or other Se-containing ligands. In humans, the $\mathrm{Hg}-\mathrm{Se}$ interaction suggests a reduction in toxicity of both inorganic mercury $(\mathrm{iHg})$ and methyl mercury $(\mathrm{MeHg})$ forms, although it should be noted that these study findings appear to be inconsistent [39].

Due to the essential functions that Se plays in human health, many studies have been undertaken to evaluate Se status in the general population, in women of reproductive age, and in pregnant women. To date, there is a paucity of such investigations in the Southern Hemisphere and as far as the literature reviews inform, no investigations have been conducted into Se levels in pregnant women nor the general population in South Africa.

The current study assessed Se status in utero at delivery and examined the possible association between Se levels and birth outcomes in coastal populations in South Africa. Furthermore, the association of Se with selected essential and toxic elements was investigated as well as possible sex-dependent responses to Se exposure in the neonates.

This study is a part of the multi-disciplinary and multi-national research collaboration between South Africa and Norway that evaluates prenatal exposures to environmental pollutants and their effects on reproductive outcomes; the study was carried out under the auspices of the Arctic Monitoring and Assessment Program (AMAP).

\section{Materials and Methods}

\subsection{Study Sites and Participants}

In total, five study sites were chosen along coastal regions of South Africa (three study sites at the Indian Ocean coast of the KwaZulu-Natal (KZN) province, and two sites at the Atlantic Ocean coast of the Western Cape province) (Figure 1). All sites were rural, except for the urban study site of the city of Cape Town, in the Western Cape province. In the statistical analyses, we report the results for total cohort, Indian Ocean region, and 
Atlantic Ocean region, which differ by environmental pollution and socioeconomic status. Women admitted for delivery at the maternity sections of public hospitals in the study regions were informed of the study objectives by the medical personnel on duty and a research assistant and invited to participate in the investigation. They were also given a detailed information pamphlet about the study. In total, 650 women agreed to take part in the study, signed informed consent forms, and agreed to donate a blood sample before delivery. Furthermore, all study participants agreed to answer a socio-demographic questionnaire by interview, which included questions on the frequency of intake of various basic foods before and during pregnancy, lifestyle, and self-reported health status. All study participants agreed to allow researchers access to the hospital birth outcome data and understood that participation was voluntary and confidential and that they had the option of withdrawing from the study at any time.

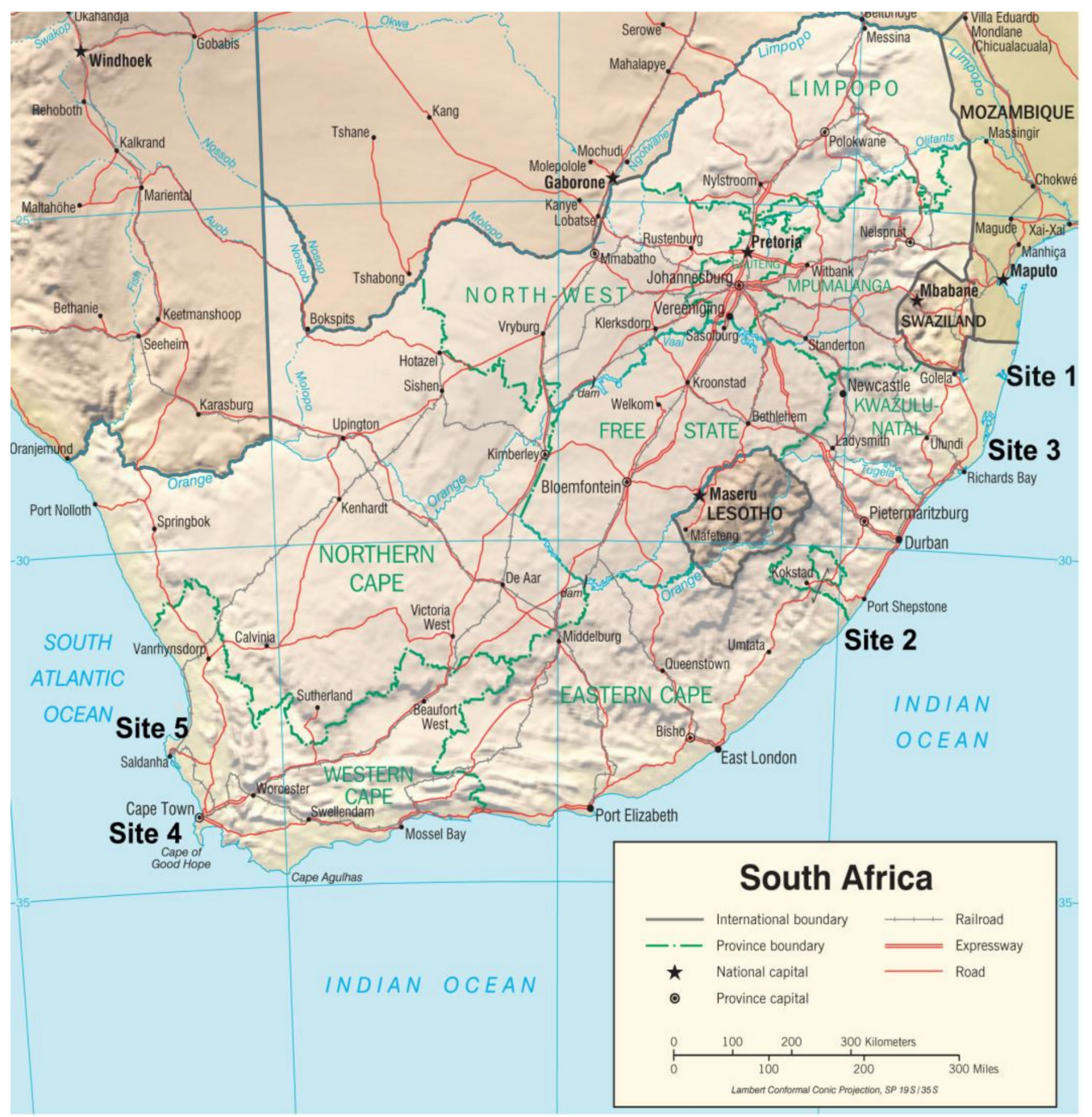

Figure 1. Study sites: Sites 1, 2, 3-Indian Ocean; sites 4 and 5-Atlantic Ocean. Figure is identical but site locations have been added, and is therefore for representative purposes only. https: / www.cia.gov/library/publications/resources/cia-maps-publications/South\% 20Africa.html. (accessed on 6 March 2017).

\subsection{Sample Collection and Analytical Procedures}

A sterile Venoject system and Becton, Dickinson \& Company (BD, Franklin Lakes, NJ, USA) collection tubes were used for all blood collections. Each study participant donated $10 \mathrm{~mL}$ of venous blood into a non-additive tube to obtain serum fractions for 
the analyses of Se, copper $(\mathrm{Cu})$, zinc $(\mathrm{Zn})$, and aluminum (Al). The serum tubes were centrifuged and the serum was transferred to acid-washed polypropylene tubes using acid-washed plastic pipettes. For the analyses of toxic elements such as $\mathrm{Hg}$, lead $(\mathrm{Pb})$, manganese (Mn), Cd, and As in maternal whole blood, $10 \mathrm{~mL}$ of venous blood was collected into tubes containing ethylene diamine tetra acetic acid (EDTA). Samples of serum (postcentrifugation) and whole blood samples were stored at $-20^{\circ} \mathrm{C}$ and couriered in a frozen state to the National Institute for Occupational Health ( $\mathrm{NIOH}$ ) laboratory, Johannesburg, South Africa. All precautions to eliminate and prevent contamination at collection and during the preparation of samples were applied throughout. All samples were analyzed using an Agilent Inductively Coupled Plasma Mass Spectrometer (ICP-MS) 7900 with an Octopole Reaction System. The serum samples were analyzed at Lancet Laboratories, Johannesburg, and whole blood samples were analyzed at the NIOH laboratory, Johannesburg, South Africa. Both laboratories participate in a proficiency testing scheme for biological samples.

\subsubsection{Serum Analyses}

For the measurement of $\mathrm{Al}, \mathrm{Cu}, \mathrm{Zn}$, and Se in serum, samples were diluted 20-fold with a diluent [ammonia $2.5 \mathrm{~mL}$; butanol $6 \mathrm{~mL}, 0.1 \%$ triton-X $50 \mu \mathrm{L}$, and EDTA (50 $\mu \mathrm{g}$ ) in $500 \mathrm{~mL}$ deionized water]. Ammonia, butanol, and EDTA were purchased from Merck Chemicals (PTY) Ltd., South Africa: Triton-X, calibration standards and internal standards were purchased from Industrial Analytical, South Africa. The following internal standards were also added to the diluent, indium (In, $25 \mu \mathrm{L}$ ), germanium (Ge, $25 \mu \mathrm{L}$ ), scandium (Sc, $25 \mu \mathrm{L}$ ), rhodium (Rh, $250 \mu \mathrm{L}$ ), and iridium (Ir, $250 \mu \mathrm{L}$ ). The ICP-MS instrument was calibrated with calibration standards prepared in a diluent using a multi-element custom standard (SPECTRASCAN-SS028226). The concentrations of the standards for $\mathrm{Se}, \mathrm{Cu}$, and $\mathrm{Zn}$ ranged from 0.1 to $100 \mu \mathrm{g} / \mathrm{L}$, and for $\mathrm{Al}$, the range was 0.1 to $50 \mu \mathrm{g} / \mathrm{L}$. The internal standards used were $\mathrm{Sc}, \mathrm{Ge}, \mathrm{Ge}$, and $\mathrm{Ir}$ for $\mathrm{Al}, \mathrm{Cu}, \mathrm{Zn}$, and Se, respectively. The instrument was run in general purpose mode using helium gas.

Two certified reference controls, Seronorm ${ }^{\mathrm{TM}}$ Trace Elements Serum (Sero Ltd., Billingstad, Norway) were analyzed with every analytical run in intervals of 10 samples for quality assurance of all element measurements. The percentage recovery for $\mathrm{Cu}, \mathrm{Zn}$, and Se was $88-104 \%$, and $91-114 \%$ for Al. The coefficient of variation was $8.76 \%, 4.56 \%$, $4.87 \%$, and $6.88 \%$ for $\mathrm{Al}, \mathrm{Cu}, \mathrm{Zn}$, and $\mathrm{Se}$, respectively. The limits of quantitation (LoQ) for $\mathrm{Al}, \mathrm{Cu}, \mathrm{Zn}$, and Se were $0.15,0.06,0.31$, and $0.17 \mu \mathrm{g} / \mathrm{L}$, respectively.

\subsubsection{Whole Blood Analysis}

The collection and analyses of samples for the selected elements manganese (Mn), $\mathrm{Hg}$, $\mathrm{Pb}, \mathrm{Cd}$, and As in maternal whole blood have been described previously [40-44].

In short, analyses for the whole blood samples were performed on an ICP-MS, following digestion in nitric acid. Two blood certified reference controls, Seronorm ${ }^{\mathrm{TM}}$ Trace Elements (Sero Ltd., Billingstad, Norway), were used. The percentage recovery of the Seronorm controls for the metals measured in blood ranged from $83-108 \%$. The detection limits for $\mathrm{Mn}, \mathrm{Hg}, \mathrm{Pb}, \mathrm{Cd}$, and As were $0.07,0.08,0.04,0.03$, and $0.13 \mu \mathrm{g} / \mathrm{L}$, respectively.

\subsection{Covariates}

Information on covariates was obtained from interviewer-administered questionnaires and hospital medical birth records of the neonates. Demographic and socio-economic status questions such as age, race/ethnicity, marital status, educational status, employment status, housing type, and source of water supply as well as self-evaluated health status were included in the questionnaire. Questions on nutrition of the mothers before and during pregnancy were also asked; these included the consumption of meat and fish, dairy products, and fruits. Additionally, the types of fuel used for the purpose of either cooking or heating were included in the questionnaire, as were smoking habits. Birth weight $(\mathrm{g})$, birth length $(\mathrm{cm})$, head circumference $(\mathrm{cm})$, gestational age (weeks), Apgar 
score at 1 and $5 \mathrm{~min}$, and placenta weight (g) were obtained from the medical records of the neonates.

\subsection{Statistical Analyses}

Data analyses were carried out using STATA version 12 [39]. The Chi-square test was used to determine if the socio-demographic and economic variables were significantly different between the two coastal regions. Bivariate analyses were carried out between Se exposure and covariates using Spearman's correlation. All the continuous variables including maternal serum Se were found to be not normally distributed and had a skewed distribution, therefore, their median and geometric mean values were calculated rather that their arithmetic means. The Wilcoxon rank-sum test was used to compare the medians of continuous variables between the two geographical populations. For the categorical variables, missing values were treated as a separate category. Multi-variable adjusted quantile regression analysis was used to explore the risk factors associated with high Se levels in maternal serum using a backward deletion approach, starting with a full model of factors significantly associated with maternal serum Se in the univariate analysis. Statistical significance was set at $p<0.05$ for all models.

\subsection{Ethical Considerations}

The study protocol was approved by the Human Research Ethics Committee of the University of Witwatersrand in Johannesburg (Protocol no. M10742), and by the Departments of Health of the different provinces. Personal data confidentiality and sample collection were carried out in accordance with The Code of Ethics of the World Medical Association (Declaration of Helsinki). Confidentiality was maintained by assigning identification numbers to all study participants.

\section{Results}

Although the total number of study participants was 650 (350 and 300 from the Indian and the Atlantic Ocean sites, respectively), the socio-economic, demographic, obstetrics, and birth outcome data reflected in Tables 1 and 2 are not for all 650 participants. This is because of non-response by some of the study participants and these are shown as additional categories, which are named "missing".

Table 1. Socio-economic, demographic, and dietary characteristics of participants in the total cohort and by regional cohorts.

\begin{tabular}{ccccc}
\hline Characteristic & $\begin{array}{c}\text { Total } \\
(n=650)\end{array}$ & $\begin{array}{c}\text { Indian Ocean } \\
(\boldsymbol{n}=\mathbf{3 5 0 )}\end{array}$ & $\begin{array}{c}\text { Atlantic Ocean } \\
(\boldsymbol{n}=\mathbf{3 0 0})\end{array}$ & $p$-Value \\
\hline Marital status $(\%, n)$ & & & $35.0(105)$ & $<0.001$ \\
\hline Married & $22.5(146)$ & $11.7(41)$ & $43.3(130)$ & \\
\hline Divorced/single/widow & $58.6(381)$ & $71.7(251)$ & $20.7(62)$ & \\
\hline Living together & $17.2(112)$ & $14.3(50)$ & $1.0(3)$ & \\
\hline Missing & $1.7(11)$ & $2.3(8)$ & $1.3(4)$ & \\
\hline Education $(\%, n)$ & & & $83(249)$ & \\
\hline None/Primary school & $8.3(54)$ & $14.3(50)$ & $14.7(44)$ & \\
\hline Secondary school & $62.0(403)$ & $44.0(154)$ & $1.0(3)$ & \\
\hline Tertiary & $25.9(168)$ & $35.4(124)$ & & \\
\hline Missing & $3.9(25)$ & $6.3(22)$ & & \\
\hline
\end{tabular}


Table 1. Cont.

\begin{tabular}{|c|c|c|c|c|}
\hline Characteristic & $\begin{array}{c}\text { Total } \\
(n=650)\end{array}$ & $\begin{array}{l}\text { Indian Ocean } \\
\quad(n=350)\end{array}$ & $\begin{array}{l}\text { Atlantic Ocean } \\
\quad(n=300)\end{array}$ & $p$-Value \\
\hline Race/Ethnicity $(\%, n)$ & & & & $<0.001$ \\
\hline African/Black & $76.6(498)$ & $96.6(338)$ & $53.3(160)$ & \\
\hline Other & $21.1(137)$ & $1.1(4)$ & $44.3(133)$ & \\
\hline Missing & $2.3(15)$ & $2.3(8)$ & $2.3(7)$ & \\
\hline Employment $(\%, n)$ & & & & $<0.001$ \\
\hline Employed & $23.5(153)$ & $13.7(48)$ & $35.0(105)$ & \\
\hline Unemployed & $74.3(483)$ & $84.0(294)$ & $63.0(189)$ & \\
\hline Missing & $2.2(14)$ & $2.3(8)$ & $2.0(6)$ & \\
\hline Housing type $(\%, n)$ & & & & $<0.001$ \\
\hline Formal housing & $60.9(396)$ & $81.4(285)$ & $37.0(111)$ & \\
\hline Flat & $4.9(32)$ & $3.4(12)$ & $6.7(20)$ & \\
\hline Backyard dwelling & $13.5(88)$ & $8.3(29)$ & $19.7(59)$ & \\
\hline Informal house (shack) & $3.4(22)$ & $4.6(16)$ & $2.0(6)$ & \\
\hline Missing & $17.2(112)$ & $2.3(8)$ & $34.7(104)$ & \\
\hline Water source $(\%, n)$ & & & & $<0.001$ \\
\hline Indoor tap & $25.9(168)$ & $10.3(36)$ & $44.0(132)$ & \\
\hline Outdoor tap & 46.9 (305) & $68.6(240)$ & $21.7(65)$ & \\
\hline Others & $9.4(61)$ & $17.4(61)$ & $0(0)$ & \\
\hline Missing & 17.9 (116) & $3.7(13)$ & $34.3(103)$ & \\
\hline Gestational age $(\%, n)$ & & & & $<0.001$ \\
\hline Pre-term (24-37 weeks) & $31.7(206)$ & $44.6(156)$ & $16.7(50)$ & \\
\hline Full-term (38-44 weeks) & $53.5(348)$ & $43.1(151)$ & 65.7 (197) & \\
\hline Missing & $14.8(96)$ & $12.3(43)$ & $17.7(53)$ & \\
\hline Cooking fuel $(\%, n)$ & & & & $<0.001$ \\
\hline Electricity & 73.7 (479) & 55.7 (195) & $94.7(284)$ & \\
\hline Paraffin & $5.2(34)$ & $7.4(26)$ & $2.7(8)$ & \\
\hline Gas/wood & $19.5(127)$ & $35.1(123)$ & $1.3(4)$ & \\
\hline Missing & $1.5(10)$ & $1.7(6)$ & $1.3(4)$ & \\
\hline Heating $(\%, n)$ & & & & $<0.001$ \\
\hline Electricity & $44.8(291)$ & $38.6(135)$ & $52.0(156)$ & \\
\hline Paraffin & $12.0(78)$ & $4.9(17)$ & $20.3(61)$ & \\
\hline Gas/wood/coal & $13.4(87)$ & $22.6(79)$ & $2.7(8)$ & \\
\hline None & $23.7(154)$ & 31.1 (109) & $15.0(45)$ & \\
\hline Missing & $6.2(40)$ & $2.9(10)$ & $10.0(30)$ & \\
\hline $\begin{array}{l}\text { Prescribed vitamin } \\
\text { supplements during } \\
\text { pregnancy }(\%, n)\end{array}$ & & & & $<0.001$ \\
\hline No supplements & $19.9(129)$ & 33.4 (117) & $4.0(12)$ & \\
\hline Supplements & $43.7(284)$ & $27.4(96)$ & $62.7(188)$ & \\
\hline Missing & $36.5(237)$ & 39.1 (137) & $33.3(100)$ & \\
\hline
\end{tabular}


Table 1. Cont.

\begin{tabular}{|c|c|c|c|c|}
\hline Characteristic & $\begin{array}{c}\text { Total } \\
(n=650)\end{array}$ & $\begin{array}{l}\text { Indian Ocean } \\
\qquad(n=350)\end{array}$ & $\begin{array}{l}\text { Atlantic Ocean } \\
\qquad(n=300)\end{array}$ & $p$-Value \\
\hline $\begin{array}{l}\text { Meat consumption before } \\
\text { pregnancy }(\%, n)\end{array}$ & & & & 0.004 \\
\hline Seldom/At least once a week & $60.5(395)$ & $66.3(232)$ & $53.7(161)$ & \\
\hline Almost everyday & $32.9(214)$ & $28.6(100)$ & $38.0(114)$ & \\
\hline Missing & $6.6(43)$ & $5.1(18)$ & $8.3(25)$ & \\
\hline $\begin{array}{c}\text { Meat consumption during } \\
\text { pregnancy }(\%, n)\end{array}$ & & & & $<0.001$ \\
\hline Seldom/At least once a week & $58.5(380)$ & $66.0(231)$ & 49.7 (149) & \\
\hline Almost everyday & $30.6(199)$ & $27.1(95)$ & $34.7(104)$ & \\
\hline Missing & $10.9(71)$ & $6.9(24)$ & $15.7(47)$ & \\
\hline $\begin{array}{l}\text { Fresh fish consumption } \\
\text { before pregnancy }\end{array}$ & & & & 0.001 \\
\hline Seldom/At least once a week & $66.8(434)$ & $62.6(219)$ & $71.7(215)$ & \\
\hline Almost everyday & $10.6(69)$ & $9.1(32)$ & $12.3(37)$ & \\
\hline Missing & $22.6(147)$ & $28.3(99)$ & $16.0(48)$ & \\
\hline $\begin{array}{l}\text { Fresh fish consumption } \\
\text { during pregnancy }(\%, n)\end{array}$ & & & & $<0.001$ \\
\hline Seldom/At least once a week & $65.4(425)$ & $61.4(215)$ & $70.0(210)$ & \\
\hline Almost everyday & $10.6(69)$ & $8.6(30)$ & $13.0(39)$ & \\
\hline Missing & $24.0(156)$ & $30.0(105)$ & $17.0(51)$ & \\
\hline $\begin{array}{c}\text { Fruit consumption before } \\
\text { pregnancy }(\%, n)\end{array}$ & & & & $<0.001$ \\
\hline Seldom/At least once a week & $23.9(155)$ & $36.3(127)$ & $9.3(28)$ & \\
\hline Almost everyday & $65.1(423)$ & $48.6(170)$ & $84.3(253)$ & \\
\hline Missing & $11.1(72)$ & $15.1(53)$ & $6.3(19)$ & \\
\hline $\begin{array}{l}\text { Fruit consumption during } \\
\text { pregnancy }(\%, n)\end{array}$ & & & & $<0.001$ \\
\hline Seldom/At least once a week & $23.4(152)$ & $36.6(128)$ & $8.0(24)$ & \\
\hline Almost everyday & $65.5(426)$ & $48.3(169)$ & $85.7(257)$ & \\
\hline Missing & $11.1(72)$ & $15.1(53)$ & $6.3(19)$ & \\
\hline $\begin{array}{l}\text { Consumed dairy products } \\
\text { before pregnancy }(\%, n)\end{array}$ & & & & $<0.001$ \\
\hline Seldom/At least once a week & $28.6(186)$ & $42.6(149)$ & $12.3(37)$ & \\
\hline Almost everyday & $57.7(375)$ & $41.7(146)$ & $76.3(229)$ & \\
\hline Missing & $13.7(89)$ & $15.7(55)$ & $11.3(34)$ & \\
\hline $\begin{array}{l}\text { Consumed dairy products } \\
\text { during pregnancy }(\%, n)\end{array}$ & & & & $<0.001$ \\
\hline Seldom/At least once a week & $27.9(181)$ & $41.7(146)$ & $11.7(35)$ & \\
\hline Almost everyday & $57.5(374)$ & $41.1(144)$ & $76.7(230)$ & \\
\hline Missing & $14.6(95)$ & $17.1(60)$ & $11.7(35)$ & \\
\hline
\end{tabular}


Table 2. The median of obstetrics and birth outcomes by total and regional cohorts.

\begin{tabular}{|c|c|c|c|c|}
\hline Characteristic & $\begin{array}{c}\text { Total } \\
(n=650)\end{array}$ & $\begin{array}{l}\text { Indian Ocean } \\
\quad(n=350)\end{array}$ & $\begin{array}{l}\text { Atlantic Ocean } \\
\quad(n=300)\end{array}$ & $p$-Value \\
\hline Maternal age (y) & 24.0 & 23.0 & 26.0 & $<0.001$ \\
\hline Maternal weight (kg) & 71.6 & 71.0 & 72.0 & 0.716 \\
\hline Maternal height (cm) & 159.0 & 160.0 & 158.0 & 0.117 \\
\hline \multicolumn{5}{|l|}{$\begin{array}{c}\text { Maternal blood pressure } \\
(\mathrm{BP}, \mathrm{mmHg})\end{array}$} \\
\hline BP Systolic & - & - & 120.0 & \\
\hline BP Diastolic & - & - & 70.0 & \\
\hline Gestational age (weeks) & 38.2 & 37.0 & 39.0 & $<0.001$ \\
\hline Birth weight (g) & 3100.0 & 3100.0 & 3100.0 & 0.295 \\
\hline Birth length $(\mathrm{cm})$ & 50.0 & 50.0 & 50.0 & 1.000 \\
\hline Head circumference $(\mathrm{cm})$ & 35.0 & 35.0 & 34.0 & $<0.001$ \\
\hline Placenta weight (g) & - & - & 600.0 & \\
\hline Apgar score $1 \min (\%, n)$ & & & & $<0.001$ \\
\hline $0-3$ & $1.4(9)$ & $1.1(4)$ & $1.7(5)$ & \\
\hline $4-6$ & $5.2(34)$ & $1.7(6)$ & $9.3(28)$ & \\
\hline $7-10$ & $85.9(558)$ & $87.4(306)$ & $84.0(252)$ & \\
\hline Missing & $7.5(49)$ & $9.7(34)$ & $5.0(15)$ & \\
\hline Apgar score $5 \mathrm{~min}$ & & & & 0.044 \\
\hline $0-3$ & $0.3(2)$ & $0.3(1)$ & $0.3(1)$ & \\
\hline $4-6$ & $0.9(6)$ & $1.1(4)$ & $0.7(2)$ & \\
\hline $7-10$ & $91.4(594)$ & $88.6(310)$ & $94.7(284)$ & \\
\hline Missing & $7.4(48)$ & $10.0(35)$ & $4.3(13)$ & \\
\hline $\operatorname{Sex}(\%, n)$ & & & & 0.596 \\
\hline Male & 49.9 (324) & $48.0(168)$ & $52.0(156)$ & \\
\hline Female & $44.6(290)$ & $46.3(162)$ & 42.7 (128) & \\
\hline Missing & $5.5(36)$ & $5.7(20)$ & $5.3(16)$ & \\
\hline Parity $(\%, n)$ & & & & 0.005 \\
\hline 0 & $42.0(273)$ & 47.7 (167) & 35.3 (106) & \\
\hline $1+$ & $54.5(354)$ & 49.4 (173) & $60.3(181)$ & \\
\hline Missing & $3.5(23)$ & $2.9(10)$ & $4.3(13)$ & \\
\hline
\end{tabular}

\subsection{Characteristics of the Study Population}

When examining the socio-economic and demographic characteristics of participants (Table 1) by geographical position (namely the Indian Ocean and Atlantic Ocean regional cohorts), significant differences between regions were evident for marital and educational status, ethnicity, unemployment situation, and access to electricity and the source of water. Participants from the Indian Ocean region reported better housing facilities with $83 \%$ residing in formal housing, whereas a greater number of participants from the Atlantic Ocean region had an indoor tap for water and electricity in their homes. Although folic acid is included in the vitamin supplements that are prescribed free of charge to all women attending antenatal clinics, only $45.1 \%$ of women from the Indian Ocean region reported taking them regularly, compared with $94 \%$ of women from the Atlantic Ocean region. 
The dietary intake of basic food items before and during pregnancy was significantly different between the two regions for fruits, meat, and dairy products. However, there was no difference between regions for the consumption of fresh fish.

\subsection{Obstetrics and Birth Outcomes} Table 2.

The descriptive data for total and regional obstetrics and birth outcomes are shown in

The average gestational age was 38.2 weeks with $49.9 \%$ of neonates being males. In the total cohort, the median age of mothers was 24.0 years with about $44 \%$ being primiparous (results not shown). There were differences in median gestational age between the Atlantic Ocean and the Indian Ocean regions (39.0 weeks vs. 37.0 weeks; $p<0.001$ ). There were no differences in the median values of maternal weight, maternal height, and birth weight, and in the categories of the Apgar scores at $5 \mathrm{~min}$ between the two regions. For the Apgar score at $1 \mathrm{~min}$, the number of neonates with scores between 7 and 10 was higher in the Indian Ocean region than in the Atlantic Ocean region (96.8\% versus $88.4 \% ; p<0.001)$.

\subsection{Serum Se Levels in Mothers and Infant Anthropometry Measures at Birth}

Spearman's rank correlation coefficient ( $p$-value) data of the associations between maternal serum Se and birth outcomes for total, pre-term, and full-term deliveries are presented in Table 3. No significant differences were observed between pre-term and full-term births with respect to maternal serum Se concentrations. The head circumference of neonates was negatively correlated with maternal serum Se levels in the total cohort $(\beta=-0.164 ; p<0.001)$ and in both the pre-term $(\beta=-0.234 ; p=0.001)$ and fullterm neonates $(\beta=-0.132 ; p=0.020)$. However, there was no correlation between maternal serum Se and birth length, birth weight, or Apgar scores at 1 min and 5 min of all the neonates.

Table 3. Spearman's rank correlation ( $p$-value) of association between maternal serum Se and birth outcomes for pre-term and full-term deliveries.

\begin{tabular}{|c|c|c|c|}
\hline Characteristic & $\begin{array}{c}\text { Total } \\
(n=554)\end{array}$ & $\begin{array}{c}\text { Pre-Term } \\
(24-37 \text { Weeks }) \\
(n=206)\end{array}$ & $\begin{array}{c}\text { Full-Term } \\
(38-44 \text { Weeks }) \\
(n=348)\end{array}$ \\
\hline Birth outcome & $\beta$ & $\beta$ & $\beta$ \\
\hline Birth length & $-0.030(0.499)$ & $-0.097(0.187)$ & $-0.016(0.780)$ \\
\hline Birth weight & $0.005(0.920)$ & $-0.062(0.402)$ & $0.010(0.855)$ \\
\hline Apgar score $1 \mathrm{~min}$ & $0.025(0.576)$ & $0.075(0.309)$ & $0.002(0.970)$ \\
\hline Apgar score $5 \mathrm{~min}$ & $-0.052(0.248)$ & $-0.059(0.419)$ & $-0.040(0.484)$ \\
\hline Head circumference & $-0.164(<0.001)^{* * *}$ & $-0.234(0.001)^{* * *}$ & $-0.132(0.020)$ * \\
\hline Parity & $0.126(0.005)^{* *}$ & $0.122(0.096)$ & $0.125(0.027)$ * \\
\hline
\end{tabular}

The main finding related to birth outcomes is that the head circumference of neonates is significantly negatively correlated with maternal serum Se levels in the total cohort $(\beta=-0.164 ; p<0.001)$ as well as in the pre-term $(\beta=-0.234 ; p=0.001)$ and full-term $(\beta=-0.132 ; p=0.020)$ cohorts. Additionally, there is a positive correlation between parity and maternal Se in the total cohort $(\beta=0.126 ; p=0.005)$ and the full-term cohort $(\beta=0.125 ; p=0.027)$.

\subsection{Concentrations of Se and Selected Essential and Toxic Elements at Delivery}

Table 4 shows the concentrations of Se in maternal serum in the total and regional cohorts. 
Table 4. Maternal serum Se concentrations ( $\mu \mathrm{g} / \mathrm{L})$-total and by regional cohorts (Indian Ocean and Atlantic Ocean).

\begin{tabular}{ccccc}
\hline $\begin{array}{c}\text { Selenium } \\
\text { Concentrations }\end{array}$ & $\begin{array}{c}\text { Total } \\
(n=635)\end{array}$ & $\begin{array}{c}\text { Indian Ocean } \\
(\boldsymbol{n}=\mathbf{3 4 5 )}\end{array}$ & $\begin{array}{c}\text { Atlantic Ocean } \\
(\boldsymbol{n}=\mathbf{2 9 0})\end{array}$ & $\boldsymbol{p}$-Value \\
\hline Se & & & & $<0.001$ \\
\hline Mean (SD) & $69.0(23.7)$ & $63.2(19.5)$ & $76.0(26.3)$ & \\
\hline Geometric mean (GM) & 65.9 & 60.8 & 72.6 & \\
\hline Range & $10-328.2$ & $26.1-182.5$ & $10.0-328.2$ \\
\hline $95 \%$ Conf. Interval & $64.4-67.5$ & $59.0-62.6$ & $70.2-75.2$ \\
\hline Median & 66.2 & 60.5 & 75.0 \\
\hline Range & $64.5-68.2$ & $26.1-182.5$ & $10-328.2$ & \\
\hline
\end{tabular}

It is evident that serum Se levels at delivery were considerably lower in the Indian Ocean cohort when compared with the Atlantic Ocean cohort. The concentrations of selected essential and toxic elements are shown in Table 5.

Table 5. Concentration of selected essential and toxic elements in serum and whole blood (as indicated) in $\mu \mathrm{g} / \mathrm{L}$.

\begin{tabular}{cccccccc}
\hline Element & $N^{*}$ & Mean (SD) & \multicolumn{2}{c}{ Range } & GM & 95\% CI & Median \\
\hline & & & Essential elements-Se, Zn Cu, Mn levels & 95\% CI \\
\hline Se serum & 635 & $69.0(23.7)$ & $10.0-328.2$ & 65.9 & $64.4-67.5$ & 66.2 & $64.49-68.16$ \\
\hline Zn serum & 637 & $503.1(148.7)$ & $127.7-1810.0$ & 483.8 & $473.4-494.4$ & 486.1 & $477.00-497.16$ \\
\hline Cu serum & 639 & $2482.2(531.0)$ & $204.8-4453.0$ & 2423.3 & $2380.5-2467.0$ & 2417.0 & $2371.40-2468.87$ \\
\hline Mn blood & 636 & $16.3(6.6)$ & $2.4-43.9$ & 15.1 & $14.6-15.6$ & 15.3 & $14.86-15.83$ \\
\hline & & & Toxic elements-Pb Hg, As, Cd, Al levels & $12.4-14.0$ & 14.0 & $13.02-15.00$ \\
\hline Pb blood & 640 & $17.7(18.5)$ & $0.4-316.9$ & 13.2 & $0.8-0.9$ & 0.7 & $0.67-0.79$ \\
\hline Hg blood & 638 & $1.2(1.6)$ & $0.2-24.2$ & 0.8 & $0.6-0.7$ & 0.7 & $0.67-0.74$ \\
\hline As blood & 641 & $0.9(0.7)$ & $0.07-6.2$ & 0.6 & $9.3-10.0$ & 9.7 & $8.94-10.80$ \\
\hline Al serum & 616 & $14.9(13.5)$ & $0.2-60.1$ & 9.1 & $0.2-0.3$ & 0.3 & $0.24-0.30$ \\
\hline Cd blood & 641 & $0.4(0.5)$ & $0.03-4.9$ & 0.3 &
\end{tabular}

$N^{*}$-Total number of samples analyzed per element differed due to missing values.

The GM $(95 \%$ CI) for Se in serum for the total cohort was $65.9 \mu \mathrm{g} / \mathrm{L}$, whereas the GM for $\mathrm{Cu}$ and $\mathrm{Zn}$ was 483.8 and $2423.3 \mu \mathrm{g} / \mathrm{L}$, respectively. The GM concentrations of $\mathrm{Mn}$ and $\mathrm{Pb}$ in blood were found to be $15.1 \mu \mathrm{g} / \mathrm{L}$ and $13.2 \mu \mathrm{g} / \mathrm{L}$, respectively. The GM for $\mathrm{Al}$ in serum was found to be $9.1 \mu \mathrm{g} / \mathrm{L}$, and the $\mathrm{GMs}$ for $\mathrm{Hg}$, As and $\mathrm{Cd}$ concentrations were $0.8 \mu \mathrm{g} / \mathrm{L}, 0.6 \mu \mathrm{g} / \mathrm{L}$, and $0.3 \mu \mathrm{g} / \mathrm{L}$, respectively.

\subsection{Spearman's Rank Correlation Association between Se and Measured Essential and Toxic Elements}

Table 6 shows the Spearman's rank correlation coefficient ( $p$-value) of the association between Se and measured essential and toxic elements at delivery in total and regional cohorts. 
Table 6. Spearman's correlation of Se and essential and toxic elements by total and regional cohorts.

\begin{tabular}{cccc}
\hline Element & $\begin{array}{c}\text { Total } \\
\text { Rho }(p \text {-Value })\end{array}$ & $\begin{array}{c}\text { Indian Ocean } \\
\text { Rho }(p \text {-Value })\end{array}$ & $\begin{array}{c}\text { Atlantic Ocean } \\
\text { Rho }(p \text {-Value })\end{array}$ \\
\hline & Se and essential element $\mathrm{Zn}, \mathrm{Cu}$, Mn levels-total and by region \\
\hline $\mathrm{Zn}$ & $0.164(<0.001)^{* * *}$ & $0.362(<0.001)^{* * *}$ & $0.269(<0.001)^{* * *}$ \\
\hline $\mathrm{Cu}$ & $0.273(<0.001)^{* * *}$ & $0.298(<0.001)^{* * *}$ & $0.338(<0.001)^{* * *}$ \\
\hline $\mathrm{Mn}$ & $-0.053(0.189)$ & $-0.053(0.332)$ & $0.046(0.449)$ \\
\hline & Se and toxic element $\mathrm{Pb}, \mathrm{Hg}, \mathrm{As}, \mathrm{Cd}, \mathrm{Al}$ levels-total and by region \\
\hline $\mathrm{Pb}$ & $-0.163(<0.001)^{* * *}$ & $-0.029(0.594)$ & $0.010(0.880)$ \\
\hline $\mathrm{Hg}$ & $0.205(<0.001)^{* * *}$ & $0.067(0.216)$ & $0.124(0.047){ }^{*}$ \\
\hline $\mathrm{As}$ & $-0.145(<0.001)^{* * *}$ & $0.069(0.202)$ & $0.055(0.379)$ \\
\hline $\mathrm{Al}$ & $0.122(0.003)^{* *}$ & $-0.041(0.451)$ & $0.171(0.006)^{* *}$ \\
\hline $\mathrm{Cd}$ & $0.094(0.020)^{*}$ & $0.132(0.015)^{*}$ & $(0.215)$ \\
\hline${ }^{*} p \leq 0.05,^{* *} p \leq 0.01,{ }^{* * *} p \leq 0.001$. & &
\end{tabular}

As expected, significant positive correlations were found between maternal Se concentrations and $\mathrm{Zn}$ and $\mathrm{Cu}$, which are essential elements, in all cohorts. In contrast, for Mn (an essential and a toxic element) there were negative correlations with Se in the total cohort and in the Indian Ocean region, but these were not statistically significant. The measured toxic elements in maternal blood showed negative and significant correlations between $\mathrm{Se}$ and $\mathrm{Pb}$ and $\mathrm{As}$ in the total cohort only. Significant positive correlations were evident between Se and both $\mathrm{Hg}$ and $\mathrm{Al}$ in the total and Atlantic Ocean cohorts. There were also positive correlations between $\mathrm{Se}$ and $\mathrm{Cd}$ in the total and Indian Ocean cohorts.

\subsection{Maternal Serum Se and Sex-Specific Association with Essential and Toxic Elements at Delivery}

Table 7 shows prenatal sex-specific Spearman's association between maternal serum Se and measured essential and toxic elements.

Table 7. Spearman's association between Se and sex-dependent response for essential and toxic elements at delivery.

\begin{tabular}{cccc}
\hline Element & $\begin{array}{c}\text { Total Cohort } \\
\text { Rho }(p \text {-Value })\end{array}$ & $\begin{array}{c}\text { Male Cohort } \\
\text { Rho }(p \text {-Value })\end{array}$ & $\begin{array}{c}\text { Female Cohort } \\
\text { Rho }(p \text {-Value })\end{array}$ \\
\hline Selected essential elements \\
\hline Zn serum & $0.164(<0.001)^{* * *}$ & $0.202(<0.001)^{* * *}$ & $0.114(0.057)$ \\
\hline Cu serum & $0.273(<0.001)^{* * *}$ & $0.236(<0.001)^{* * *}$ & $0.323(<0.001)^{* * *}$ \\
\hline Mn blood & $-0.053(0.189)$ & $-0.096(0.091)$ & $0.005(0.935)$ \\
\hline Selected toxic elements & \\
\hline Pb blood & $-0.163(<0.001)^{* * *}$ & $-0.185(0.001)^{* * *}$ & $-0.118(0.053)^{*}$ \\
\hline Hg blood & $0.205(<0.001)^{* * *}$ & $0.243(<0.001)^{* * *}$ & $0.189(0.002)^{* *}$ \\
\hline As blood & $-0.145(<0.001)^{* * *}$ & $-0.092(0.110)$ & $-0.179(0.003)^{* *}$ \\
\hline Al serum & $0.122(0.003)^{* * *}$ & $0.159(0.006)^{* *}$ & $0.065(0.286)$ \\
\hline Cd blood & $0.094(0.020)^{*}$ & $0.105(0.068)$ & $0.073(0.232)$ \\
\hline${ }^{* *} \leq 0.05, * * p \leq 0.01{ }^{* * *} p \leq 0.001$. & &
\end{tabular}

Significant positive correlations were found between maternal Se concentrations and maternal $\mathrm{Zn}$ levels in the total and male cohorts, with a marginal significance level also observed in the female cohort. In all cohorts, maternal $\mathrm{Cu}$ serum was positively correlated with the maternal Se concentration. For the toxic elements, maternal blood Pb levels were negatively and significantly correlated with maternal Se concentrations in the total and 
male cohorts. Maternal Hg concentrations were positively associated with maternal Se in all three cohorts. Maternal Se was negatively associated with As in all three cohorts, but found to be of statistical significance only for the total and female cohorts. The Al levels, on the other hand, were positively and significantly associated with maternal serum Se levels in the total and male cohorts. However, Cd levels in blood were significantly correlated with Se levels in serum only in the total cohort.

\subsection{Univariate and Multi-Variable Regression Analyses}

Results of univariate and multi-variable quantile regression at $50 \%$ are shown in Table 8 . In the univariate regression, head circumference was the only birth outcome measured that was associated with maternal Se levels, while parity and maternal age were the only obstetric outcomes that were associated with maternal Se. There was an association between maternal Se and all essential elements, except for Mn. There was also a significant association between maternal Se and dietary and supplement intake during pregnancy.

Table 8. Coefficient estimates of quantile regression at 50\% quantile-univariate and multi-variable regression.

\begin{tabular}{|c|c|c|c|c|c|c|}
\hline \multirow[b]{2}{*}{ Characteristic } & \multicolumn{3}{|c|}{ Univariate } & \multicolumn{3}{|c|}{ Multi-Variable } \\
\hline & Coefficient & $p$-Value & $95 \%$ CI & Coefficient & $p$-Value & $95 \% \mathrm{CI}^{*}$ \\
\hline Head circumference & -1.205 & 0.007 & -2.083 to -0.327 & - & - & - \\
\hline Apgar score $1 \mathrm{~min}$ & -0.442 & 0.570 & -1.969 to 1.085 & - & - & - \\
\hline Apgar score $5 \mathrm{~min}$ & -1.495 & 0.206 & -3.813 to 0.823 & - & - & - \\
\hline Birthweight & -0.002 & 0.217 & -0.006 to 0.001 & - & - & - \\
\hline Birth length & -0.250 & 0.346 & -0.769 to 0.270 & - & - & \\
\hline \multicolumn{7}{|l|}{ Parity } \\
\hline 0 & 1.0 & & & & & \\
\hline 1 & 4.993 & 0.006 & 1.412 to 8.574 & - & - & - \\
\hline \multicolumn{7}{|l|}{ Region } \\
\hline Indian & 1.0 & & & & & \\
\hline Atlantic & 14.460 & $<0.001$ & 11.287 to 17.633 & - & - & - \\
\hline Gestational age & 0.178 & 0.707 & -0.752 to 1.108 & - & - & - \\
\hline Maternal age & 0.328 & 0.022 & 0.048 to 0.608 & 0.367 & 0.004 & 0.121 to 0.612 \\
\hline Maternal weight & 0.062 & 0.325 & -0.062 to 0.186 & - & - & - \\
\hline Maternal height & -0.086 & 0.373 & -0.274 to 0.103 & - & - & - \\
\hline $\mathrm{Zn}$ & 0.018 & 0.005 & $0.005-0.030$ & 0.022 & $<0.001$ & 0.111 to 0.033 \\
\hline $\mathrm{Cu}$ & 0.010 & $<0.001$ & 0.007 to 0.013 & 0.008 & $<0.001$ & 0.005 to 0.011 \\
\hline $\mathrm{Mn}$ & -0.262 & 0.060 & -0.534 to 0.011 & - & - & - \\
\hline $\mathrm{Pb}$ & -0.115 & 0.018 & -0.211 to -0.020 & - & - & - \\
\hline $\mathrm{Hg}$ & 3.264 & $<0.001$ & 2.251 to 4.277 & - & - & - \\
\hline As & -2.118 & 0.092 & -4.585 to 0.350 & - & - & - \\
\hline $\mathrm{Al}$ & 0.368 & $<0.001$ & 0.242 to 0.494 & - & - & - \\
\hline $\mathrm{Cd}$ & 5.007 & 0.006 & 1.451 to 8.564 & - & - & - \\
\hline
\end{tabular}


Table 8. Cont.

\begin{tabular}{|c|c|c|c|c|c|c|}
\hline \multirow[b]{2}{*}{ Characteristic } & \multicolumn{3}{|c|}{ Univariate } & \multicolumn{3}{|c|}{ Multi-Variable } \\
\hline & Coefficient & $p$-Value & $95 \% \mathrm{CI}$ & Coefficient & $p$-Value & $95 \% \mathrm{CI} *$ \\
\hline \multicolumn{7}{|l|}{ Location } \\
\hline Rural & 1.0 & & & & & \\
\hline Urban & 12.130 & $<0.001$ & 8.456 to 15.804 & - & - & - \\
\hline \multicolumn{7}{|l|}{ Race } \\
\hline African/Black & 1.0 & & & 1.0 & & \\
\hline Other & 11.730 & $<0.001$ & 7.925 to 15.535 & 13.505 & $<0.001$ & 9.735 to 17.275 \\
\hline \multicolumn{7}{|l|}{$\begin{array}{c}\text { Smoked during } \\
\text { pregnancy }\end{array}$} \\
\hline No & 1.0 & & & & & \\
\hline Yes & 6.420 & 0.001 & 2.731 to 10.109 & - & - & - \\
\hline \multicolumn{7}{|l|}{$\begin{array}{c}\text { Consumed dairy } \\
\text { products before } \\
\text { pregnancy }\end{array}$} \\
\hline $\begin{array}{l}\text { Seldom/At least } \\
\text { once a week }\end{array}$ & 1.0 & & & & & \\
\hline Almost everyday & 6.402 & 0.001 & 2.567 to 10.238 & - & - & - \\
\hline \multicolumn{7}{|l|}{$\begin{array}{l}\text { Consumed dairy } \\
\text { products during } \\
\text { pregnancy }\end{array}$} \\
\hline $\begin{array}{l}\text { Seldom/At least } \\
\text { once a week }\end{array}$ & 1.0 & & & & & \\
\hline Almost everyday & 6.800 & $<0.001$ & 3.000 to 10.603 & - & - & - \\
\hline \multicolumn{7}{|l|}{$\begin{array}{l}\text { Consumed fruits } \\
\text { before pregnancy }\end{array}$} \\
\hline $\begin{array}{l}\text { Seldom/At least } \\
\text { once a week }\end{array}$ & 1.0 & & & & & \\
\hline Almost everyday & 7.630 & 0.001 & 3.026 to 12.235 & - & - & - \\
\hline \multicolumn{7}{|l|}{$\begin{array}{l}\text { Consumed fruits } \\
\text { during pregnancy }\end{array}$} \\
\hline $\begin{array}{l}\text { Seldom/At least } \\
\text { once a week }\end{array}$ & 1.0 & & & & & \\
\hline Almost everyday & 7.540 & 0.001 & 3.043 to 12.037 & - & - & - \\
\hline \multicolumn{7}{|l|}{ Use of supplements } \\
\hline No supplement use & 1.0 & & & & & \\
\hline Supplement use & 6.070 & 0.024 & 0.796 to 11.344 & - & - & - \\
\hline
\end{tabular}

In the multi-variable regression, maternal age, serum $\mathrm{Zn}$, serum $\mathrm{Cu}$, and race were associated with maternal Se levels. Compared to black Africans, study participants from other racial groups were more likely to have higher maternal Se levels (Coeff: 13.505; 95\% Conf. Interval: 9.735 to 17.275). Additionally, the greater the maternal age, the higher the level of maternal Se (Coeff: 0.367; 95\% Conf. Interval: 0.121 to 0.612 ).

\section{Discussion}

The current study has determined the Se status in utero at the delivery stage in a large cohort of pregnant women, residing along both the Indian and Atlantic Oceans 
coastal regions of South Africa. Highly significant differences in Se levels were found between the populations with participants from the rural Indian Ocean sites presenting with lower Se levels. This finding may indicate that some socio-economic, lifestyle, and dietary practices can be contributory factors. When compared with other studies, Se levels measured in our study were similar to those reported from Spain by Navarro et al. (1996) and those reported from Malawi and Ethiopia in pregnant populations $[45,46]$. On the other hand, the Se mean concentrations in our South African cohort 69.0(23.7) $\mu \mathrm{g} / \mathrm{L}$ were lower than those reported from Kuwait, North Norwegian, and Korean pregnant populations, 107.3(6.9) $\mu \mathrm{g} / \mathrm{L}, 73(15) \mu \mathrm{g} / \mathrm{L}$, and median $94 \mu \mathrm{g} / \mathrm{L}$, respectively [47-49].

Studies that have investigated Se levels at different stages of pregnancy have reported the lowest Se concentrations in the third trimester of pregnancy and at delivery. For example, Liu et al. (2017) showed that median Se levels in pregnant Chinese women declined from $77.6 \mu \mathrm{g} / \mathrm{L}$ in the first trimester to $65 \mu \mathrm{g} / \mathrm{L}$ in the third trimester [50].

To date, there are no published data on human Se levels in South Africa, but research has been conducted to investigate Se status in grazing herbivores. These studies report marginal to acute Se deficiencies in parts of the KwaZulu-Natal province and in the southern coastal region of the Western Cape province [51]; coincidentally, both of these geographical areas are the coastal sites where the current study was conducted. As the participants in the current study reside in Se-deficient geographical areas of South Africa, we can presume that their Se intake during pregnancy is low, but further studies are needed to confirm this assumption. Based on this information, the risk to immune, nervous, and reproductive systems during the developmental stages cannot be ruled out in the South African population. Ongoing research has already shown that deficiency of Se in pregnant women may result in damage to these systems. For example, low serum concentrations of Se in the first trimester of pregnancy have been shown to be a predictor of low birth weight in neonates [52]. A study performed in Australia found that an excessive dietary intake of Se was associated with prolonged pregnancy. In contrast, Se levels in Japanese pregnant women were not related to pre-term births $[53,54]$. These findings indicate the need to investigate the effect of supplementary intake of Se not only in pregnant women, but also in the general population. Although there have been no extensive studies in South Africa on the use of dietary supplements containing Se, it is expected that the use of supplements will be less in the lower income groups. This expectation was confirmed by a nutritional study performed in South Africa that used self-administered questionnaires at two health centers at the Atlantic Ocean site. The study demonstrated that supplement users were mainly females with higher incomes [55]. Similar to our findings, the intake of dietary supplements was found to be low among black African women residing in the UK [56]. However, without more research it is difficult to conclude whether black African women have lower Se levels due to their reduced supplement and dietary intake or because of other factors such as genetic make-up [57]. When examining birth outcomes, the current study found that the head circumference of neonates was significantly and negatively correlated with maternal serum Se levels in the total cohort $(\beta=-0.164 ; p<0.001)$ as well as in the pre-term and full-term cohorts. Our literature review did not find any studies reporting an association between Se levels and neonate head circumference, suggesting the need for further investigation. No other effects of Se on birth outcomes were present in our study, although other researchers have reported an effect of Se on birth weight [58].

Essential trace elements including Se regulate and maintain various organ systems in humans and their deficiency or excess may create a number of pathological conditions, particularly during the developmental stages. In South Africa, all women attending prenatal clinics are prescribed free supplements, but we have established that not all are actually taking supplements due to various traditional beliefs and social reasons. Our study found a significant positive correlation between maternal serum Se and the levels of the essential elements $\mathrm{Zn}$ and $\mathrm{Cu}$ in all cohorts. In contrast, some studies have found a negative correlation between Se and $\mathrm{Zn}$ in pregnant women, but significant positive correlations between maternal Se and $\mathrm{Cu}[59,60]$. This investigation found that $\mathrm{Mn}$ (which 
is both an essential and toxic element) showed a marginal negative correlation with Se in the total and Indian Ocean cohorts, but these were not statistically significant.

The protective role of Se in the exposure to environmental toxic elements was also evaluated in the current study. It is important to note that all toxic elements measured $(\mathrm{Pb}$, $\mathrm{Hg}$, As, and $\mathrm{Cd}$ in maternal blood, and $\mathrm{Al}$ in maternal serum) were present in all samples and their concentrations were above the detection limits of the analytical instruments. In the total cohort, a significant negative correlation was found between maternal Se and $\mathrm{Pb}$ levels. It is reported that the competition between $\mathrm{Se}$ and $\mathrm{Pb}$ for binding with functional bio-ligands and/or in vivo formation of lead selenide are the protective mechanisms to consider [61]. Similarly, our study found a negative correlation between Se and As concentrations in the total cohort and a positive correlation for $\mathrm{Cd}$ in both the total and the Indian Ocean cohorts. These findings are in agreement with Zwolak (2020), who suggested that Se can reduce As- or Cd-mediated toxicity in major organs such as spleen, liver, kidney, brain, and heart in animal models and in cell culture studies, irrespective of Se form [62]. It is postulated that Se protects against the toxicity of As and Cd either by converting these metals into biologically inert compounds and/or through the action of Se-dependent antioxidant enzymes. It is also proposed that Se reduces As toxicity by increasing the As methylation efficiency. The current study found significantly positive correlations between $\mathrm{Se}$ and $\mathrm{Hg}$ levels in the total and Atlantic Ocean cohorts. It has been reported that a primary molecular mechanism to reduce toxicity of $\mathrm{Hg}$ is due the ability of $\mathrm{Hg}$ to bind to selenide or Se-containing ligands [39]. Complexes formed in such a way are irreversible, and thus, biologically inactive. In the case of Se deficiency, the impairment of normal synthesis of selenoproteins and their expression can be anticipated.

In terms of an association with $\mathrm{Al}$, the present study found a significant positive correlation with Se concentrations in the total and Atlantic Ocean cohorts. In a mouse animal model, a protective effect of Se on aluminum-induced oxidative stress in liver has been recently reported [63], and Se has also been found to be effective in preventing cardiovascular damage caused by aluminum chloride in rats.

Evidence is growing for the establishment of sex-related differences in the response to prenatal exposure to environmental toxicants and dietary intake [64,65]. These studies attribute the sex-related differences to the structure and function of the placenta. In our investigation, we found evidence that the positive correlations between Se levels and essential and toxic elements may be sex-specific. The Se levels in the male cohort were positively associated with $\mathrm{Zn}, \mathrm{Cu}, \mathrm{Hg}$, and $\mathrm{Al}$ levels, but negatively associated with $\mathrm{Pb}$ concentrations in whole blood. In the female cohort, a positive response was found for serum $\mathrm{Cu}$ and blood $\mathrm{Hg}$, but a negative response was evident for blood As. Reports on sex-related differences in exposure, absorption, metabolism, and detoxification support the theory of susceptibility for sex-specific metal toxicity and that male neonates have a greater dependence on their mothers' diet during gestation. Studies regarding sex differences in susceptibility to the effects of toxic and essential elements on fetal development remain scarce and there is an urgent need for large scale studies to investigate prenatal sex-specific responses to essential and toxic metal exposures.

In the final univariate analysis model, the following parameters were positively associated with Se levels: living at the Atlantic Ocean site, increase in maternal age, and increased $\mathrm{Cu}, \mathrm{Zn}, \mathrm{Hg}$, and $\mathrm{Al}$ concentrations. Head circumference and $\mathrm{Pb}$ level were negatively associated with Se levels. However, only the following parameters showed significant associations with $\mathrm{Se}$ in the multi-variable regression model: maternal age, $\mathrm{Cu}$ and $\mathrm{Zn}$ levels, and being of non-African ethnicity. In addition, Se levels were found to be positively associated with maternal age, as was also shown by other researchers who attributed this to a greater health awareness as one ages $[66,67]$.

\section{Conclusions}

The current study investigated Se status at delivery as a measure of in utero access to selected essential trace elements, and exposure to certain toxic metals during gestation. 
To the best of our knowledge, this is the first study in South Africa that has evaluated Se status in the developmental stages, in a large cohort of delivering women. Our study found that Se levels were comparably lower than those reported from countries in the Northern Hemisphere, and negatively associated with head circumference of neonates, indicating the need for further investigation. Furthermore, this study has shown a significant correlation between Se and other essential trace elements such as $\mathrm{Cu}$ and $\mathrm{Zn}$, which was also evident in the multi-variable regression model. Our study is also the first in South Africa to examine Se levels and sex-dependent responses in utero to both essential and toxic elements.

The authors are aware that the present study has a number of limitations, one being reliance on participant memory for information on diet and lifestyle. Although every effort was made to obtain reliable information such as conducting interviews in the participants home language, there may still have been information bias due to misinterpretation, cultural misunderstanding, or poor recall. Another limitation is the fact that for practical and logistical reasons, all participants were recruited from government hospitals and no subjects were recruited from private hospitals, introducing an economic bias to the study. The cross-sectional design of the study was also a limiting factor. The study findings will form a baseline for further investigations in other areas of South Africa as well as in the rest of Africa; the findings may inform public health and regulatory agencies in formulating reproductive health policies.

Author Contributions: Conceptualization, H.B.R. and J.Ø.O.; methodology, K.C. and H.B.R.; software, B.O.; validation B.O. and H.B.R.; formal analysis, B.O. and K.C.; resources, South African Medical Research Council (SAMRC); data curation. B.O.; writing-original draft, H.B.R., K.C., B.O., and J.Ø.O.; writing-review and editing, H.B.R., K.C., B.O., and J.Ø.O.; supervision H.B.R. and K.C.; project administration H.B.R. and J.Ø.O.; funding acquisition, H.B.R. and J.Ø.O.; All authors have read and agreed to the published version of the manuscript.

Funding: Funding for this study was provided by the National Research Foundation (NRF), South Africa and the Research Council of Norway (Grant 114962; HB Röllin, SA PI), the Arctic Monitoring and Assessment Program (AMAP), and the Norwegian Royal Ministry for Foreign Affairs (RER-09/126, JØ Odland). The funding agencies did not contribute to the experimental design, the execution of the study, data analysis, nor the preparation of the manuscript.

Institutional Review Board Statement: The study protocol was approved by the Human Research Ethics Committee of the University of Witwatersrand in Johannesburg (Protocol no. M10742), and by the Departments of Health of the different provinces. Personal data confidentiality and sample collection were carried out in accordance with The Code of Ethics of the World Medical Association (Declaration of Helsinki). Confidentiality was maintained by assigning identification numbers to all study participants.

Informed Consent Statement: Informed consent was obtained from all participants. The participation was voluntary and confidential and participants had the option of withdrawing from the study at any time.

Data Availability Statement: Part of these data are still unpublished and under ongoing assessment and not available publicly yet.

Acknowledgments: The authors would like to thank the participants, employees at the hospitals, and other health officials involved in this research study. The authors also sincerely thank the funding institutions for financial assistance. Special thanks are due to Tahira Kootbodien and Miriam Mogotsi from the Medical Research Council, South Africa (SAMRC) for their expert research assistance, and Claudina Nogueira (UP and the International Commission on Occupational Health -ICOH) for reviewing and proof reading of the manuscript.

Conflicts of Interest: The authors declare no conflict of interest.

\section{References}

1. WHO. Selenium in Drinking Water, Background Document for Development of WHO Guidelines for Drinking-Water Quality; WHO: Geneva, Switzerland, 2011.

2. Kabata-Pendias, A. Geochemistry of selenium. J. Environ. Pathol. Toxicol. Oncol. 1998, 17, 173-177. 
3. Hurst, R.; Siyame, E.W.; Young, S.D.; Chilimba, A.D.; Joy, E.J.; Black, C.R.; Ander, E.L.; Watts, M.J.; Chilima, B.; Gondwe, J.; et al. Soil-type influences human selenium status and underlies widespread selenium deficiency risks in Malawi. Sci. Rep. $2013,3,1425$. [CrossRef]

4. IOM, Institute of Medicine (US) Panel on Dietary Antioxidants and Related Compounds. Dietary Reference Intakes for Vitamin C, Vitamin E, Selenium, and Carotenoids; National Academies Press: Washington, DC, USA, 2000.

5. EFSA. Panel on Dietetic Products, Nutrition and Allergies (NDA). Allergies, Scientific Opinion on Dietary Reference Values for selenium. EFSA J. 2014, 12, 3846. [CrossRef]

6. Fairweather-Tait, S.J.; Bao, Y.; Broadley, M.R.; Collings, R.; Ford, D.; Hesketh, J.E.; Hurst, R. Selenium in human health and disease. Antioxid. Redox. Signal 2011, 14, 1337-1383. [CrossRef]

7. Hoffmann, P.R.; Berry, M.J. The influence of selenium on immune responses. Mol. Nutr. Food Res. 2008, 52, 1273-1280. [CrossRef] [PubMed]

8. Hurst, R.; Armah, C.N.; Dainty, J.R.; Hart, D.J.; Teucher, B.; Goldson, A.J.; Broadley, M.R.; Motley, A.K.; Fairweather-Tait, S.J. Establishing optimal selenium status: Results of a randomized, double-blind, placebo-controlled trial. Am. J. Clin. Nutr. 2010, 91, 923-931. [CrossRef]

9. Kryukov, G.V.; Castellano, S.; Novoselov, S.V.; Lobanov, A.V.; Zehtab, O.; Guigó, R.; Gladyshev, V.N. Characterization of mammalian selenoproteomes. Science 2003, 300, 1439-1443. [CrossRef] [PubMed]

10. Brown, K.M.; Arthur, J.R. Selenium, selenoproteins and human health: A review. Public Health Nutr. 2001, 4, 593-599. [CrossRef]

11. Köhrl, J.; Brigelius-Flohé, R.; Böck, A.; Gärtner, R.; Meyer, O.; Flohé, L. Selenium in biology: Facts and medical perspectives. Biol. Chem. 2000, 381, 849-864. [CrossRef]

12. Arthur, J.R.; McKenzie, R.C.; Beckett, G.J. Selenium in the immune system. J. Nutr 2003, 133 (Suppl. 1), 1457S-1459S. [CrossRef]

13. Barrington, J.W.; Taylor, M.; Smith, S.; Bowen-Simpkins, P. Selenium and recurrent miscarriage. J. Obstet. Gynaecol. 1997, 17, 199-200.

14. Combs, G.F.; Gray, W.P. Chemopreventive agents: Selenium. Pharmacol. Ther. 1998, 79, 179-192. [CrossRef]

15. Hawkes, W.C.; Hornbostel, L. Effects of dietary selenium on mood in healthy men living in a metabolic research unit. Biol. Psychiatry 1996, 39, 121-128. [CrossRef]

16. Nève, J. Selenium as a risk factor for cardiovascular diseases. J. Cardiovasc. Risk. 1996, 3, 42-47. [CrossRef]

17. Rudge, C.V.; Röllin, H.B.; Nogueira, C.M.; Thomassen, Y.; Rudge, M.C.; Odland, J. The placenta as a barrier for toxic and essential elements in paired maternal and cord blood samples of South African delivering women. J. Environ. Monit. 2009, 11, 1322-1330. [CrossRef] [PubMed]

18. Sakamoto, M.; Chan, H.M.; Domingo, J.L.; Koriyama, C.; Murata, K. Placental transfer and levels of mercury, selenium, vitamin E, and docosahexaenoic acid in maternal and umbilical cord blood. Environ. Internat. 2018, 111, 309-315. [CrossRef] [PubMed]

19. Santos, C.; Garcia-Fuentes, E.; Callejon-Leblic, B.; Garcia-Barrera, T.; Gomez-Ariza, J.L.; Rayman, M.P.; Velasco, I. Selenium, selenoproteins and selenometabolites in mothers and babies at the time of birth. Br. J. Nutr. 2017, 117, 1304-1311. [CrossRef]

20. Chen, Z.; Myers, R.; Wei, T.; Bind, E.; Kassim, P.; Wang, G.; Ji, Y.; Hong, X.; Caruso, D.; Bartell, T.; et al. Placental transfer and concentrations of cadmium, mercury, lead, and selenium in mothers, newborns, and young children. J. Expo. Sci. Environ. Epidemiol. 2014, 24, 537-544. [CrossRef]

21. Nandakumaran, M.; Dashti, H.M.; Surname, F. Maternal-fetal transport kinetics of copper, selenium, magnesium and iron in perfused human placental lobule: In vitro study. Mol. Cell Biochem. 2002, 231, 9-14. [CrossRef]

22. Combs, G.F. Food system-based approaches to improving micronutrient nutrition: The case for selenium. Biofactors 2000, 12, 39-43. [CrossRef] [PubMed]

23. Stuss, M.; Michalska-Kasiczak, M.; Sewerynek, E. The role of selenium in thyroid gland pathophysiology. Endokrynol. Pol. 2017, 68, 440-465. [CrossRef]

24. Zimmermann, M.B.; Köhrle, J. The impact of iron and selenium deficiencies on iodine and thyroid metabolism: Biochemistry and relevance to public health. Thyroid 2002, 12, 867-878. [CrossRef] [PubMed]

25. Li, S.; Xiao, T.; Zheng, B. Medical geology of arsenic, selenium and thallium in China. Sci. Total. Environ. 2012, 421-422, 31-40. [CrossRef] [PubMed]

26. Keshan, Disease Research Group. Epidemiologic studies on the etiologic relationship of selenium and Keshan Disease. Chin. Med. J. 1979, 92, 477-482.

27. Johnson, R.A.; Baker, S.S.; Fallon, J.T.; Maynard, E.P.; Ruskin, J.N.; Wen, Z.; Ge, K.; Cohen, H.J. An accidental case of cardiomyopathy and selenium deficiency. N. Engl. J. Med. 1981, 304, 1210-1212. [CrossRef]

28. Duntas, L.H.; Benvenga, S. Selenium: An element for life. Endocrine 2015, 48, 756-775. [CrossRef]

29. Rayman, M.P. Selenium and human health. Lancet 2012, 379, 1256-1268. [CrossRef]

30. Al-Kunani, A.S.; Knight, R.; Haswell, S.J.; Thompson, J.W.; Lindow, S.W. The selenium status of women with a history of recurrent miscarriage. Br. J. Obstet. Gynaecol. 2001, 108, 1094-1097.

31. Liu, P.J.; Yao, A.; Ma, L.; Chen, X.Y.; Yu, S.L.; Liu, Y.; Hou, Y.X. Associations of Serum Selenium Levels in the First Trimester of Pregnancy with the Risk of Gestational Diabetes Mellitus and Preterm Birth: A Preliminary Cohort Study. Biol. Trace Elem. Res. 2021, 199, 527-534. [CrossRef]

32. Rayman, M.P.; Searle, E.; Kelly, L.; Johnsen, S.; Bodman-Smith, K.; Bath, S.C.; Mao, J.; Redman, C.W. Effect of selenium on markers of risk of pre-eclampsia in UK pregnant women: A randomised, controlled pilot trial. Br. J. Nutr. 2014, 112, 99-111. [CrossRef] 
33. Makwe, C.C.; Nwabua, F.I.; Anorlu, R.I. Selenium status and infant birth weight among HIV-positive and HIV-negative pregnant women in Lagos, Nigeria. Nig. Q. J. Hosp. Med. 2015, 25, 209-215.

34. Alexander, E.K.; Pearce, E.N.; Brent, G.A.; Brown, R.S.; Chen, H.; Dosiou, C.; Grobman, W.A.; Laurberg, P.; Lazarus, J.H.; Mandel, S.J.; et al. Guidelines of the American Thyroid Association for the Diagnosis and Management of Thyroid Disease during Pregnancy and the Postpartum. Thyroid 2017, 27, 315-389. [CrossRef] [PubMed]

35. Nuttall, K.L. Evaluating selenium poisoning. Ann. Clin. Lab. Sci. 2006, 36, 409-420.

36. Nehru, L.B.; Bansal, M.P. Effect of selenium supplementation on the glutathione redox system in the kidney of mice after chronic cadmium exposures. J. Appl. Toxicol. 1997, 17, 81-84. [CrossRef]

37. Ponomarenko, O.; La Porte, P.F.; Singh, S.P.; Langan, G.; Fleming, D.E.B.; Spallholz, J.E.; Alauddin, M.; Ahsan, H.; Ahmed, S.; Gailer, J.; et al. Selenium-mediated arsenic excretion in mammals: A synchrotron-based study of whole-body distribution and tissue-specific chemistry. Metallomics 2017, 9, 1585-1595. [CrossRef] [PubMed]

38. Wan, N.; Xu, Z.; Liu, T.; Min, Y.; Li, S. Ameliorative Effects of Selenium on Cadmium-Induced Injury in the Chicken Ovary: Mechanisms of Oxidative Stress and Endoplasmic Reticulum Stress in Cadmium-Induced Apoptosis. Biol. Trace Elem. Res. 2018, 184, 463-473. [CrossRef] [PubMed]

39. Kuraś, R.; Janasik, B.; Wassowicz, W.; Stanisławska, M. Revision of reciprocal action of mercury and selenium. Int. J. Occup. Med. Environ. Health 2018, 31, 575-592.

40. Channa, K.; Odland, J.; Kootbodien, T.; Theodorou, P.; Naik, I.; Sandanger, T.M.; Röllin, H.B. Differences in prenatal exposure to mercury in South African communities residing along the Indian Ocean. Sci. Total Environ. 2013, 463-464, 11-19. [CrossRef] [PubMed]

41. Röllin, H.B.; Channa, K.; Olutola, B.G.; Odland, J. Evaluation of in utero exposure to arsenic in South Africa. Sci. Total Environ. 2017, 575, 338-346. [CrossRef] [PubMed]

42. Röllin, H.B.; Kootbodien, T.; Channa, K.; Odland, J. Prenatal Exposure to Cadmium, Placental Permeability and Birth Outcomes in Coastal Populations of South Africa. PLoS ONE 2015, 10. [CrossRef] [PubMed]

43. Röllin, H.B.; Kootbodien, T.; Theodorou, P.; Odland, J. Prenatal exposure to manganese in South African coastal communities. Environ. Sci. Process. Impacts 2014, 16, 1903-1912. [CrossRef]

44. Röllin, H.B.; Olutola, B.; Channa, K.; Odland, J. Reduction of in utero lead exposures in South African populations: Positive impact of unleaded petrol. PLoS ONE 2017, 12. [CrossRef]

45. Kassu, A.; Yabutani, T.; Mulu, A.; Tessema, B.; Ota, F. Serum zinc, copper, selenium, calcium, and magnesium levels in pregnant and non-pregnant women in Gondar, Northwest Ethiopia. Biol. Trace Elem. Res. 2008, 122, 97-106. [CrossRef]

46. Navarro, M.; López, H.; Pérez, V.; López, M.C. Serum selenium levels during normal pregnancy in healthy Spanish women. Sci. Total Environ. 1996, 186, 237-242. [CrossRef]

47. Al-Saleh, E.; Nandakumaran, M.; Al-Shammari, M.; Al-Harouny, A. Maternal-fetal status of copper, iron, molybdenum, selenium and zinc in patients with gestational diabetes. J. Matern. Fetal Neonatal. Med. 2004, 16, 15-21. [CrossRef]

48. Hansen, S.; Nieboer, E.; Sandanger, T.M.; Wilsgaard, T.; Thomassen, Y.; Veyhe, A.S.; Odland, J.O. Changes in maternal blood concentrations of selected essential and toxic elements during and after pregnancy. J. Environ. Monit. 2011, 13, $2143-2152$. [CrossRef] [PubMed]

49. Choi, R.; Sun, J.; Yoo, H.; Kim, S.; Cho, Y.Y.; Kim, H.J.; Kim, S.W.; Chung, J.H.; Oh, S.Y.; Lee, S.Y. A Prospective Study of Serum Trace Elements in Healthy Korean Pregnant Women. Nutrients 2016, 8, 749. [CrossRef]

50. Liu, X.; Zhang, Y.; Piao, J.; Mao, D.; Li, Y.; Li, W.; Yang, L.; Yang, X. Reference Values of 14 Serum Trace Elements for Pregnant Chinese Women: A Cross-Sectional Study in the China Nutrition and Health Survey 2010-2012. Nutrients 2017, 9, 309. [CrossRef] [PubMed]

51. Van Ryssen, J.B.J. Geographical distribution of the selenium status of herbivores in South Africa. S. Afr. J. Anim. Sci. 2001, 31, 1-7. [CrossRef]

52. Pieczyńska, J.; Grajeta, H. The role of selenium in human conception and pregnancy. J. Trace Elem. Med. Biol. 2015, 29, 31-38. [CrossRef] [PubMed]

53. Tsuji, M.; Shibata, E.; Morokuma, S.; Tanaka, R.; Senju, A.; Araki, S.; Sanefuji, M.; Koriyama, C.; Yamamoto, M.; Ishihara, Y.; et al. The association between whole blood concentrations of heavy metals in pregnant women and premature births: The Japan Environment and Children's Study (JECS). Environ. Res. 2018, 166, 562-569. [CrossRef] [PubMed]

54. Chiudzu, G.; Choko, A.; Maluwa, A.; Huber, S.; Odland, J. Maternal serum concentration of selenium, copper and zinc during pregnancy are associated with risk of spontaneous preterm birth: A case control study from Malawi. medRxiv 2020. medRxiv:2020.04.14.20064717. [CrossRef]

55. Braun, M.V.I. Use of dietary supplements, and awareness and knowledge of the recommended fruit and vegetable intakes and consumption of health food store customers in the Cape Town city bowl. S. Afr. J. Clin. Nutri. 2008, 21, 323-330. [CrossRef]

56. Adegboye, A.R.; Ojo, O.; Begum, G. The Use of Dietary Supplements Among African and Caribbean Women Living in the UK: A Cross-Sectional Study. Nutrients 2020, 12, 847. [CrossRef]

57. Laclaustra, M.; Stranges, S.; Navas-Acien, A.; Ordovas, J.M.; Guallar, E. Serum selenium and serum lipids in US adults: National Health and Nutrition Examination Survey (NHANES) 2003-2004. Atherosclerosis 2010, 210, 643-648. [CrossRef]

58. Bogden, J.D.; Kemp, F.W.; Chen, X.; Stagnaro-Green, A.; Stein, T.P.; Scholl, T.O. Low-normal serum selenium early in human pregnancy predicts lower birth weight. Nutr. Res. 2006, 26, 497-502. [CrossRef] 
59. Cengiz, B.; Söylemez, F.; Oztürk, E.; Cavdar, A.O. Serum zinc, selenium, copper, and lead levels in women with second-trimester induced abortion resulting from neural tube defects: A preliminary study. Biol. Trace Elem. Res. 2004, 97, 225-235. [CrossRef]

60. Izquierdo Alvarez, S.; Castañón, S.G.; Ruata, M.L.; Aragüés, E.F.; Terraz, P.B.; Irazabal, Y.G.; González, E.G.; Rodríguez, B.G. Updating of normal levels of copper, zinc and selenium in serum of pregnant women. J. Trace Elem. Med. Biol. 2007, 21 (Suppl. 1), 49-52. [CrossRef] [PubMed]

61. Flora, S.J.S.; Singh, S.; Tandon, S.K. Role of Selenium in Protection against Lead Intoxication. Acta Pharmacol. Toxicol. 1983, 53, 28-32. [CrossRef]

62. Zwolak, I. The Role of Selenium in Arsenic and Cadmium Toxicity: An Updated Review of Scientific Literature. Biol. Trace Elem. Res. 2020, 193, 44-63. [CrossRef] [PubMed]

63. Viezeliene, D.; Jansen, E.; Rodovicius, H.; Kasauskas, A.; Ivanov, L. Protective effect of selenium on aluminium-induced oxidative stress in mouse liver in vivo. Environ. Toxicol. Pharmacol. 2011, 31, 302-306. [CrossRef] [PubMed]

64. Gabory, A.; Roseboom, T.J.; Moore, T.; Moore, L.G.; Junien, C. Placental contribution to the origins of sexual dimorphism in health and diseases: Sex chromosomes and epigenetics. Biol. Sex Differ. 2013, 4, 5. [CrossRef]

65. Rosenfeld, C.S. Sex-Specific Placental Responses in Fetal Development. Endocrinology 2015, 156, 3422-3434. [CrossRef] [PubMed]

66. Caillie-Bertrand, M.V.; Degenhart, H.J.; Fernandes, J. Influence of Age on the Selenium Status in Belgium and The Netherlands. Pediatr. Res. 1986, 20, 574-576. [CrossRef] [PubMed]

67. Galan, P.; Viteri, F.E.; Bertrais, S.; Czernichow, S.; Faure, H.; Arnaud, J.; Ruffieux, D.; Chenal, S.; Arnault, N.; Favier, A.; et al. Serum concentrations of beta-carotene, vitamins $\mathrm{C}$ and $\mathrm{E}$, zinc and selenium are influenced by sex, age, diet, smoking status, alcohol consumption and corpulence in a general French adult population. Eur. J. Clin. Nutri. 2005, 59, 1181-1190. [CrossRef] [PubMed] 